\title{
Morphosyntax Analysis of Acehnese Clitic
}

\author{
Denni Iskandar ${ }^{1,2}$, Mulyadi $^{2}$, Iskandar Abdul Samad ${ }^{3}$. \\ ${ }^{1,2}$ Indonesian Education Department of Syiah Kuala University, Banda Aceh, Indonesia \\ ${ }^{2}$ Linguistic Department, University of Sumatera Utara, Medan, Indonesia \\ ${ }^{3}$ English Education Department of Syiah Kuala University, Banda Aceh, Indonesia
}

Corresponding Author: Iskandar Abdul Samad, E-mail: iskandar.abdul.samad@unsyiah.ac.id

\begin{tabular}{|c|c|}
\hline ARTICLE INFO & ABSTRACT \\
\hline Article history & \multirow{8}{*}{$\begin{array}{l}\text { Clitic has challenged many grammatical theories because it is a combination between syntax and } \\
\text { morphology. At most theory, clitization is considered as a phenomenon of phrase because the } \\
\text { clan of its form is similar to affixes attached to whole phrase. Some experts claim that clitic is } \\
\text { one form that is difficult to identify and classify. This qualitative research investigates the clitic } \\
\text { of Acehnese in the perspective of morphosyntax. This research found that Acehnese consists of } \\
\text { proclitic and enclitic. The function is to emphasize the topic being talked by the subject. In general, } \\
\text { Acehnese clitic is a relatively complex personal pronoun because Acehnese's pronominal system } \\
\text { is identical with the content of morality (politeness and friendship). Each personal pronoun has } \\
\text { its own proclitic and enclitic including the adjustment of clitic for variant personal pronouns } \\
\text { which refers to the level of politeness. In addition to personal pronoun, the clitic in Acehnese is } \\
\text { also used to refer to noun or nounphrase either to animals, plants, or other types of nouns. }\end{array}$} \\
\hline Received: April 03, 2018 & \\
\hline Accepted: July 08, 2018 & \\
\hline Published: August 31, 2018 & \\
\hline Volume: 9 Issue: 4 & \\
\hline Advance access: July 2018 & \\
\hline Conflicts of interest: None & \\
\hline Funding: None & \\
\hline
\end{tabular}

Key words:

Clitic,

Proclitic,

Enclitic,

Acehnese,

Personal Pronoun,

Politeness

\section{INTRODUCTION}

The discussion of clitic in the Acehnese, to date, has not been conducted deeply by many researchers. So far the points which are close to this topic is found in the sub-section of dissertations (e.g.Asyik, 1987; Djunaidi, 1996) and thesis (e.g. Djunaidi, 1992; Iqbal, 2011). Even in the book of the Acehnese Language Rule written by Wildan (2010), there is no discussion about the clitic because he considers that clitic is similar to affix. This fact encourages us to conduct a research on the Acehnese clitic because this language is used by more than three million people in Aceh Province, Indonesia.

The clitic in Acehnese is a summary of personal pronoun which is divided into two types, namely proclitic and enclitic. Proclitic is a concise form of first, second and third pronouns which are attached in front of a word, whereas the enclitic is a concise form of first, second and third pronouns which are attached at the end of a word. The two forms can be arranged not only to a basic word, but also to a word that has been given an affix.

Proclitic and enclitic are different from affix. Affix has no relationship with another form, whereas proclitic or enclitic has a relationship with another form, that is with personal pronoun. In Acehnese, there is a matching system between agents and verbs or adjectives. This term of conformity is named as agreement system by Asyik (1987) or clocalization by Durie (1985). For example gob nyan or 'he/she' is summed up as geu- and geutanyoe or 'we' which are shortened into $t a$-. This form should actually not be treated equally with affixes because it acts as a personal pronoun. However, this form is treated as an affix as well, where the writing is supplemented with the basic word.

Clitic is a difficult form to be identified and classified. Halpern (in Spencer and Zwicky, 2001, p. 101) suggests that to distinguish free words or phrases from affixes is very clear; however, many languages have various formative that are difficult to classify and to categorize. The formative is named as clitic.

Zwicky (Katamba, 1993) states that almost all languages have a morpheme that is difficult to analyze because it does not show clear limits whether it is included into the category of words or affixes. Morpheme that is difficult to categorize is called clitic. This phenomenon makes it difficult for linguists to provide an adequate definition of clitic. Even 
Hudson $(2007$, p. 2) says that clitic is a challenge in grammatical architecture because of the behavior of language that is in between word boundaries and morphemes and between syntax and morphology. Marantz (1988) says that clitic is a unit of words for syntax and a morpheme for morphology and phonology.

Djunaidi (1992) argues that the use of clitic in the Acehnese is not only used in personal pronouns, however, it is also used to refer to a noun or a noun phrase of animals, plants or other nouns that are not animated. Clitic in the Acehnese also potentially describes the agent which has control over the events stated in the predicate.

One of the uniqueness of the Acehnese is to have a fairly complex pronoun system. In addition, the use of the Acehnese pronomina is identical with the content of morality (politeness/friendship). This is because the Acehnese pronouns recognize the level of decency. For example, the second single pronoun droeneuh 'you' is more polite than gata 'you', let alone from kah 'you' which is considered rude. Similarly, the first single personal pronouns of the Acehnese which consists of three levels, namely ulontuwan or lontuwan 'saya' (very polite), ulon, lon, long, ulong 'me' (polite), and kèe 'me' (rough, friendship). This is, of course, also closely related to the clitic of the Acehnese since it is a pronominal clitic.

The finding of this research would be benefit as a teaching material in teaching Acehnese for either native or nonnative speakers. Currently, Acehnese is one of local content subjects at junior and senior high schools in Aceh. This finding would be useful to increase the quality of the instructional materials. Teaching materials are essential for teachers that help them find it easier to teach the students in the classroom and students could feel a sense of improvement.

\section{LITERATURE REVIEW}

Many researchers give attention on clitic. Bauer (1988,p. 99) argues that clitic is a form of contraction of a word with its independent existence. Its forms, such as 've,'d, 's, and '1l as contractions of have, had, has, and will are examples of clitic in English. Katamba (1994, p. 245) explaines “...there is another class of bound morphemes called clitic, the which may be appended to the independent words syntactically motivated by rules. Words to which clitic are attached are called hosts (or anchors)... Clitics attached to the beginning of a host is called an enclosure and one attached to the end is called an enclitic. "

In contrast to Bauer who says that clitic is the word, Katamba defines clitic as a distinct class of bound morphemes added to words that are independent because of rules that are syntactically motivated. The clitic is then attached to the so-called words hosts or anchors. If the clitic is attached at the beginning of the host, it is called proclitic, and if it is attached to the end of the host, it is called the enclitic.

Based on its phonological behavior, clitic is an element that does not have accent and is not a basic form of inflection affix and derivative affixes. Clitic does not receive accent either inherently or in contraction, so clitic must be incorporated with a companion structure such as a stressful word or phrase called host. If there is a prosody unit with a host located next to its left, it is called an enclitic, and if the host is to the right of the prosodic unit, it is called proclitic (Halpern, 2001, p. 101). Furthermore, Halpern also said that the nature of clitic is that it must be always attached to the companion structure that get the pressure which is used as a differentiator clitic with an independent word.

A number of studies that examine clitic among others are Cliticization and the Evolution of Morphology: A Cross-linguistic Study on Phonology in Grammaticalization (Schiering, 2006), Clitics In Four Dialects Of Modern Greek: A Dynamic Account (Chatzikyriakidis, 2010), Deconstructing Catalan Object Clitics (Martin, p. 2012), The Agrammatic Comprehension of Contrastive Focus and Clitic Left Dislocation in Catalan (Salmons, p. 2015), Object Clitics And Null Objects in The Acquisition Of French (Gruter, p. 2006), Reflexive Clitics in the Slavic and Romance Languages. A Comparative View from an Antipassive Perspective (Medová, 2009), and The Morphosyntax of Tagalog Clitics: A Typologically Driven Approach (Kaufman, 2010).

\section{METHODOLOGY}

This is qualitative research in which the data used is not in the form of numbers (Cresswell, 2009), but in the form of verbal, specifically tangible form (Muhadjir, 1996, p. 29). The method used is a descriptive method, which is a method used by collecting, compiling, classifying, reviewing and interpreting data. Collecting data was done using recording technique and log technique (Sudaryanto, 1992, p. 33). After collecting the data, we used elicitation techniques (Djajasudarma, 2006, p. 61). This technique is used because we are the native speakers of Acehnese. This is in line with de Saussure's (1916) structuralism which states that every element of language is related to each other (the whole unified).

\section{RESULTS}

From the results of data analysis, it is found that clitic in Acehnese consists of proclitic and encliticas mentioned in the following Table. 1

\section{Proclitic}

Proclitic is a conformity of personal pronouns attached in front of other words so as to form a unity. Proclitic in Acehnese is available on first, second, and third personal pronouns in both singular and plural forms. The proclitic form in the Acehnese depends on the personal pronoun that is the reference. Each personal pronoun has their respective proximalities as shown in Table 1 above.

\section{Proclitic of first personal pronouns}

The use of proclitic first personal pronoun in Acehnese sentences can be observed in the following examples. 
Table 1. Clitic in acehnese

\begin{tabular}{|c|c|c|c|c|}
\hline Personal & Single & Plural & Proclitic & Enclitic \\
\hline \multirow[t]{6}{*}{ First } & Lon 'I' & & Lon- & - Lon \\
\hline & Lontuan «I' & & Lon- & -Lon \\
\hline & Ulontuan 〈I' & & Lon- & -Lon \\
\hline & Kèe 'I' & & $K u-$ & $-K u h$ \\
\hline & & Kamoe 'we' & Meu-/teu- & - Meuh \\
\hline & & Geutanyoe 'we' & $\mathrm{Ta}-$ & $-T e u h$ \\
\hline \multirow[t]{6}{*}{ Second } & Gata 'you' & & $T a-$ & $-T e u h$ \\
\hline & Droeneuh 'you' & & $\mathrm{Neu}-$ & $-N e u h$ \\
\hline & Kah 'you' & & $K^{\mathrm{o}} a^{\mathrm{o}_{-}}$ & - Keuh \\
\hline & & Gata+num <you+num’ & $T a-$ & $-T e u h$ \\
\hline & & Droeneuh+num «you+num' & $\mathrm{Neu}-$ & $-N e u h$ \\
\hline & & Kah+num «you+num’ & $K a-$ & - Keuh \\
\hline \multirow[t]{6}{*}{ Third } & Jih 'him/her' & & $J i-/ i-$ & $-I h$ \\
\hline & Gobnyan 'him/her' & & Geu- & - Geuh \\
\hline & Droeneuhnyan 'him/her' & & $\mathrm{Neu}$ & $-N e u h$ \\
\hline & & Awaknyan 'them' & $J i-$ & $-I h$ \\
\hline & & Awakjeh 'them' & $J i-$ & $-I h$ \\
\hline & & Awaknyoe 'them' & $J i-$ & $-I h$ \\
\hline
\end{tabular}

(1)

\begin{tabular}{llllll}
\hline Lontuan & Lon-meuruno & Teuga & Supaya & Luloh & Ujian. \\
\hline I & 1-learn & Very hard & To & Pass & Exam \\
\hline \multicolumn{6}{c}{ 'I learn very hard to pass the exam.' } \\
\hline
\end{tabular}

(2)

\begin{tabular}{|c|c|c|c|c|c|c|c|}
\hline Kèe & Ku -pajoh & Boh & Drien & Buklam & Bak & Keudèe & Nyan. \\
\hline I & 1-eat & Fruit & Durian & $\begin{array}{l}\text { Last } \\
\text { night }\end{array}$ & At & Shop & That \\
\hline
\end{tabular}

\begin{tabular}{|c|c|c|c|c|c|}
\hline \multicolumn{6}{|c|}{ 'I ate durian at that shop last night.' } \\
\hline Kamoe & Meu-koh & Padé & Bak & Uroe & Aleuhad. \\
\hline $\mathrm{We}$ & 1-cut & Paddy & On & Day & Sunday \\
\hline
\end{tabular}

(4)

\begin{tabular}{llllll}
\hline Geutanyoe & Ta-pubuet & Sipeu-peu & Bek & Na & Ria. \\
\hline We & 1-do & Samething & Do not & Be & Proud \\
\hline \multicolumn{6}{c}{ 'We can not do something with full of proud.' } \\
\hline
\end{tabular}

From the above sentences it appears that proclitic lon- is attached to the verb meuruno 'learn' (1), proclitic $k u$-is attached to the verb pajoh 'eat' (2), proclitic meu- is attached to the verb koh 'cut' (3), and proclitic ta- is attached to the verb pubuet 'create' (4). These four proliferations are the conformity of the actors: lon is the conformity of lontuan 'me', ku- is the conformity of kèe 'me', meu- is the conformity of kamoe 'us', and ta-is the conformity of geutanyoe 'us'. The word lontuan 'me' is more polite to use than the word kèe 'I'.

\section{Proclitic of Second Personal Pronouns}

The use of the second personal pronoun proclitic in the Acehnese can be observed in the following sentences.

\begin{tabular}{lllll}
\hline Gata & Pat & Ta-teumè & Kitab & Nyan? \\
\hline You & Where & 2-find & Book & That \\
\hline \multicolumn{4}{c}{ 'Where do you find that books?' } \\
\hline
\end{tabular}

(6)

\begin{tabular}{llll}
\hline Drouneuh & Yang & Toh & Neu-piléh? \\
\hline You & Conj & Which & 2-choose \\
\hline \multicolumn{4}{c}{ 'Which one do you choose?' } \\
\hline Kah & & \\
\hline You & Peue & Ka-pajoh? \\
\hline \multicolumn{4}{c}{ What } \\
\hline
\end{tabular}

The above sentences have shown that proclitic $t a$ is attached to the verb teume or 'find' (5), proclitic neu is attached to the verb piléh 'choose' (6), and proclitic $k a$ - is attached to the verb pajOh 'eat' (7). The three proclitics are the conformity of the actors that can be explained as follows: $t a$ - is the conformity of gata 'you', neu- is conformity of drouneuh 'you', and ka-is the conformity of kah 'you'. The word drouneuh 'you' is more polite to use than the word gata 'you'; while the word gata 'you' is more polite to use than kah 'you'.

In the nonformal variety, the second personal pronoun can be omitted and it is sufficient to use the clitic only. The word gata in the sentence "Gata pat ta-teumè 
kitab nyan?" can be shortened into "Pat ta-teumè kitab nyan?". The word drouneuh in the phrase "Drouneuh toh neu-piléh? - can be "Yang toh neu-piléh?". The word kah in the phrase "Kah peue ka-pajOh?" can be "Peue ka-pajOh?".

\section{Proclitic of Third Personal Pronoun}

The use of the third proclitic personal pronouns in Acehnese sentences can be observed in the following sentences.

(8)

\begin{tabular}{lllll}
\hline Jih & Ho & Ji-wo & Lawet & Nyoe? \\
\hline He/she & Where & 3-return & Time & This \\
\hline \multicolumn{5}{c}{ 'Where did he/she go home nowadays?' } \\
\hline
\end{tabular}

(9)

\begin{tabular}{llllll}
\hline Gobnyan & Geu-bloe & Bajèe & Baro & Keu & Lon. \\
\hline He/she & 3-bought & Clothes & New & For & $\mathrm{Me}$ \\
\hline \multicolumn{7}{c}{ 'He/she bought me a new cloth.' } \\
\hline
\end{tabular}

(10)

\begin{tabular}{llllll}
\hline Awaknyan & Ji-pubuet & Karu & Bak & kanto & Geutanyoe. \\
\hline They & 3-make & Problem & In & Office & Our \\
\hline \multicolumn{6}{c}{ 'They make a problem in our office.' } \\
\hline
\end{tabular}

From the above sentences it appears that proclitic $j i$ - is attached to the verb wo or 'home' (8), proclitic geu- is attached to the verb bloe 'buy' (9), and proclitic ji- is attached to the verb pubuet 'create' (10). These three proclitics are the conformity of the actors: $j i$ - is the conformity of $j i h$ 'he', geu- is the conformity of gobnyan 'he', and ji- is the conformity of awaknyan 'their'. Here, it appears that $j i$ is used as a single person pronoun proclitic pronoun ( $g o b$ nyan) and is used also for the third plural proclitic personal pronoun (awaknyan). The word gobnyan 'he/she' is more polite to use than the word jih 'him/her'.

As Djunaidi (1992) points out, the proclitic ji- is not only used as a single personal pronoun, but is also used to refer to noun agents or noun phrase of animals, plants, or other nouns as in the following examples. (11)

\begin{tabular}{llll}
\hline Manok & Nyan & Teungoh & Ji-meu-pakée. \\
\hline Chicken & Itu & Asp & 3-Pref-fight \\
\hline \multicolumn{4}{c}{ 'The chicken is fighting.' } \\
\hline
\end{tabular}

(12)

\begin{tabular}{llll}
\hline Mamplam & Nyan & $\boldsymbol{K a}$ & Ji -meu-bungong. \\
\hline Mango & Itu & Asp & 3-Pref-flower \\
\hline \hline & 'The mango is already flowering.' \\
\hline
\end{tabular}

(13)

\begin{tabular}{|c|c|c|c|c|c|}
\hline Geulanteu & Ji-meu-su & That & Kreuh & Dari & Baroe. \\
\hline Thunder & 3-Pref-Sounds & Very & Loud & Since & Yesterday \\
\hline
\end{tabular}

The above sentences show that proclitic $j i$ - is not only used as the personal pronoun, but it can also be used for animals, like manok 'chicken' (11), plants like mamplam 'mango', and other inanimate nouns like geulanteu 'thunder'.

\section{A combination of action verb and proclitic}

Proclitic in Acehnese always demands on the presence of agents in sentences, both explicit and implicit, especially agents who act as the actor. This happens not only in personal pronouns but also on nouns of either animate or not. This indicates that morphologically, proclitic is attached to the action verb. In Grammar, verb is classified in terms of actions, circumstances, and processes. The use of proclitic describes that potentially agents have control over events stated in the predicate. On the other hand, without proclitic, behavioral control is low.

A series of proclitic identifies the existence of actors in a sentence. In other words, proclitic can be found in active sentence. This could be seen from the existence of actors and target. The above sentence can be taken as examples, meu-koh 'to cut' (3), ta-teumè 'to find out' (5), geu-bloe 'to buy' (9), dan ji-pubuet 'to do' (10). From these examples, it is identified that the verbs have proclitic meu-, ta-, geu-, dan ji-. These four proclitics are adjustments from actors' attitude, as in kamoe 'we' (3), gata 'you' (5), gobnyan 'you' (9), and awaknyan 'they' (10).

The action verbs in Acehnese are grouped into four parts: (a) The basic action verb, the action verb that requires an action by a person. This type of verb is accompanied by two cases, namely the actor and the target. The actor states "cause", while the target case represents something directly affected by the action or the outcome of the action. Verbs belonging to this verb include drop ' to catch', sok ' to wear', poh ' to hit', sipak ' to kick', and rhom 'to throw'.

(b) Verbs of the eksperensial action, namely the action verb which requires that the actions actors do that cause changes in the psychological state of others. For examples the verb kheun ' to say', peuasa 'disappointing', pakat 'to invite', and peupuah 'to satisfy'.

(c) Verbs of benevactive action, ie action verbs that require that the actor actions cause "benefactor" to gain or lose something. Examples of these verbs include bri 'give', suron 'send', teurimong 'accept', tulOng 'help', bantu 'help each other', and peuba 'bring'.

(d) Locative action verbs, namely action verbs that require the acts perpetrated by the actor cause the displacement of an object. Examples of these verbs include jak 'go', tamong 'enter', teubiet 'out', pinah 'moved', and meuranto 'immigrate'.

The combination of the action verbs and proclitic can be seen in detail in Table 2 below:

Although the proclitic is found in the actor active sentence, proclitic in Acehenese may have possibility to construct passive voice as in the following examples.

(14)

\begin{tabular}{lllll}
\hline Blang & Geutanyoe & Geu-mu'u & L̀̀ & Gobnyan. \\
\hline Rice field & Our & 3-cultivate & By & Him \\
\hline \multicolumn{5}{c}{ 'Our rice field is cultivated by him.' } \\
\hline
\end{tabular}


Table 2. The combination of the action verbs and proclitic

\begin{tabular}{llll}
\hline $\begin{array}{l}\text { Types of } \\
\text { actions }\end{array}$ & Verb & Meaning & Proclitic+verb \\
\hline Basic & Drop & 'To catch' & Lon-drop \\
& Sok & 'To use' & Ta-sok \\
& Poh & 'To hit' & Neu-poh \\
& Sipak & 'To kick' & Geu-sipak \\
Eksperensial & Kheun & 'To say' & Lon-kheun \\
& Peuasa & 'Dissappoint' & Ta-peuasa \\
& Hei & 'To tell' & Neu-hei \\
& Peupueh & 'To satisfy' & Ji-peupueh \\
Benevactive & Bri & 'To give' & Lon-bri \\
& Teurimong & 'To receive' & Neu-teurimong \\
& Tulong & 'To help' & Geu-tulong \\
& Bantu & 'To help each & Ji-bantu \\
& & other' & \\
Locative & Jak & 'To go' & Lon-jak \\
& Tamong & 'To enter' & Ta-tamong \\
& Minah & 'To move' & Geu-minah \\
& Meuranto & 'To immigrate' & Ji-meuranto \\
\hline
\end{tabular}

(15)

\begin{tabular}{llllll}
\hline Pue & Peuraho & Nyoe & Neu-peugot & Lè & Droeneuh? \\
\hline Is & Canoe & This & 2-do & By & You \\
\hline \multicolumn{5}{c}{ 'Is this canoe done by you?' } \\
\hline
\end{tabular}

\section{Enclitic}

Enclitic is a personal pronoun arranged behind other words that form a single unit. The enclitic of the Acehnese is available in the first, second, and third personal pronouns in both singular and plural forms. The form of enclitic in the Acehnese depends on the personal pronoun which is the reference. Each personal pronoun has enclitic respectively as shown in Table 1 above.

A new enclitic may be attached if the subject experiences a state or condition specified by the verb. This category include the meanings of (a) moods, for example galak 'like', weuh 'pitty', luwat 'disgust', and so on; (b) the condition of the body, for example teungeut 'asleep', lagak 'pretty', deuk 'hungry', and so on; (c) the ability, for example carong 'smart', bangai 'stupid', and so on; (d) attitude, for example mbOng 'arrogant', lisék 'ingenious', buhak 'lie' and so on (Iqbal, 2011, p. 65).

\section{Enclitic of The First Personal Pronouns}

The use of the first personal pronoun's enclosure in Acehnese phrase can be observed in the following sentences.

(16)

\begin{tabular}{lllll}
\hline Lontuan & Weuh-lon & Keu & Ureung & Gasin. \\
\hline I & pity-1 & To & Person & Poor \\
\hline \multicolumn{5}{c}{ 'I feel sorry for the poor.' } \\
\hline
\end{tabular}

(17)

\begin{tabular}{llll}
\hline Kèe & Sijuek-kuh & Bengoh & Nyoe \\
\hline I & Cold-1 & Morning & This \\
\hline \multicolumn{4}{c}{ 'I'm cold this morning.' } \\
\hline
\end{tabular}

(18)

\begin{tabular}{llllll}
\hline Kamoe & Ka & Glak-meuh & Keu & Akai & Gobnyan. \\
\hline We & Asp & fed up-1 & With & Behavior & His \\
\hline \multicolumn{5}{c}{ 'We're fed up with his behavior.' } \\
\hline
\end{tabular}

(19)

\begin{tabular}{lllllll}
\hline Geutanyoe & GugOp-teuh & Sabab & Tarèk & That & Uroe & Nyoe. \\
\hline We & Hot-1 & Because & Hot & Very & Day & This \\
\hline \multicolumn{6}{c}{ 'We are hot because it is so hot today.' } \\
\hline
\end{tabular}

From the sentences above, the enclitic -lon isattached to the verb weuh or 'pitty' (16), enclitic -kuh is attached to the verb sijuek 'cold' (17), enclitic -meuh is attached to the verb glak 'disgusted' (18), and enclitic -teuh is attached to the verb gugob 'hot' (19). The four enclitics is the conformity of the actors: -lon is the conformity of lontuan ' $\mathrm{I}$ ', $k u h$ - is the conformity of kèe ' $\mathrm{I}$ ', meuh- is the conformity of $k a$ moe or 'we', and -teuh is the conformity of geutanyoe 'we'.

\section{Enclitic of the Second Personal Pronouns}

The use of enclitic of the second personal pronoun in the Acehnese phrase can be observed in the following sentences. (20)

\begin{tabular}{lllll}
\hline Gata & Pue & Hana & Teungeut-teuh & Beuklam? \\
\hline You & What & Not & Sleep-2 & Last night \\
\hline \multicolumn{4}{c}{ 'You did not sleep last night?' } \\
\hline
\end{tabular}

(21)

\begin{tabular}{llllll}
\hline DroeneuhBek & Buhak-neuh Keu & Ureung & Gampong. \\
\hline You & Do not & Lie-2 & To & People & Village \\
\hline \multicolumn{5}{r}{ 'You do not lie to the villagers.' } \\
\hline
\end{tabular}

\begin{tabular}{lllll}
\hline Kah & Beu-jeumot-keuh & Meureuno & Bah & Carong. \\
\hline You & Pref-dilligent-2 & learn & To be & Smart \\
\hline \multicolumn{4}{c}{ 'You must be dilligent in learning to be a smart student.' } \\
\hline
\end{tabular}

From the sentences above, it can be seen that the enclitic -teuh is attached to the verb teungeut 'sleep' (20), enclitic-neuh is attached to the verb buhak'lie'(21), and enclitic-keuh is attached to the verb jeumot 'dilligent' (22). The three enclitics are the conformity of the actors: -teuh is the conformity of gata 'you', -neuh is the conformity of droeneuh 'you' and keuh-is the adjustment from kah 'you'.

\section{Enclitic of the Third Personal Pronouns}

The use of enclitic of the third personal pronouns in the Acehnese phrase can be observed in the following sentences. 
(23)

\begin{tabular}{lll}
\hline $\boldsymbol{J i h}$ & That & Lisèk- $\boldsymbol{i h}$. \\
\hline $\mathrm{He} / \mathrm{She}$ & Very & Clever \\
\hline \multicolumn{3}{c}{} \\
\hline
\end{tabular}

\begin{tabular}{|c|c|c|c|c|c|c|}
\hline Gobnyan & That & Yoe-geuh & Meunyoe & Hana & LulOh & Ujian. \\
\hline $\mathrm{He} / \mathrm{She}$ & Very & afraid -3 & If & Does not & Pass & Exam \\
\hline
\end{tabular}

\begin{tabular}{llll}
\hline Droeneuhnyan & Memang & Carong-neuh & Pegahhaba. \\
\hline He/She & Really & Good-3 & Speaking \\
\hline \multicolumn{4}{c}{ 'He is really good at speaking.' } \\
\hline
\end{tabular}

From the sentences above, it can be seen that enclitic -ih is attached to the verb lisék 'smart' (23), enclitic -geuh is attached to the verb yo 'afraid' (24), and enclitic -neuh is atached to the verb carong 'clever' (25). These three enclitics are the conformity of the actors: $-i h$ is the conformity of jih 'him/her', -geuh is the conformity of gobnyan 'him/her', and -neuh is the conformity of droeneuhnyan 'him/her'.

\section{Structure that is required by enclitic}

Enclitic is required when a verb or an adjective in a sentence is followed by an object. The object following the adjective is always preceded by the preposition keu 'for'. While the verbs can be followed by the object without the preposition keu, although generally use the preposition keu. Verbs and adjectives that can be followed by objects such as galak 'love', banci 'hate', peurumen 'care', beungeh 'angry', weueh 'sad', and ceumuru 'jealous' as the example of the following sentence.

(26)

\begin{tabular}{lllll}
\hline Gobnyan & Galak-geuh & Keu & Inong & Nyan \\
\hline He & Like-3 & Prep & Girl & That \\
\hline \multicolumn{5}{c}{ 'He likes that girl.' } \\
\hline
\end{tabular}

(27)

\begin{tabular}{llllll}
\hline Peu & Na & Beungeh-keuh & Keu & Ureueng & Nyan? \\
\hline Are Asp & Angry-2 & Prep & People & That \\
\hline "Are you angry to that people?' \\
\hline
\end{tabular}

On the other hands, enclitic is not always attached on the verb or adjectives. The enclitic could also be attached on other constituents as in the following sentences: (28)

\begin{tabular}{lllll}
\hline Ayah & Reubah & lam & krueng-geuh & Baroe \\
\hline Father & Fall & Prep & River-3 & Yesterday \\
\hline \multicolumn{4}{c}{ 'Father fell down to the river yesterday.' } \\
\hline
\end{tabular}

(29)

\begin{tabular}{llll}
\hline Apa & Mantong & Di & Rumoh-geuh. \\
\hline Uncle & Still & Prep & House \\
\hline \multicolumn{4}{c}{ 'Uncle is still in his house'. } \\
\hline
\end{tabular}

The above sentence shows that enclitic geuh is not attached on the verb or adjective, however, it is attached on the noun krueng 'river' (28) and rumoh 'house' (29).

In another form, enclitic is also attached on the word located at the end of a sentence.

(30)

\begin{tabular}{lllll}
\hline Ka-jok & Peng & Bek & Sampo & Deuk-jih. \\
\hline 2-give & Money & Do not & Reach & Hungry-3 \\
\hline \multicolumn{5}{c}{ 'Please give him money, do not } \\
\hline \begin{tabular}{l} 
make him hungry.' \\
\hline Paknek
\end{tabular} & Teusie & Ngon & Sikin & Jaroe-geuh \\
\hline Grandfather & slice & Prep & Knive & Hand-3 \\
\hline \multicolumn{6}{c}{ 'Grandfather's hand is sliced by knive.' } \\
\hline
\end{tabular}

The above sentences indicate that enclitics jih 'him' (30) and geuh 'him' (31) are located at the end of the sentences.

\section{The combination of clitic and enclitic}

In Acehnese, clitic and enclitic can be attached to the same verb in one sentence as presented in the following examples. (32)

\begin{tabular}{llllll}
\hline Apa & Lon & Teungoh & Geu-manoe-geuh & Lam & Krueng. \\
\hline Uncle & My & Asp & 3-take a bath-3 & Prep & River \\
\hline \multicolumn{6}{c}{ My uncle is taking a bath in the river.' } \\
\hline
\end{tabular}

\begin{tabular}{llllll}
\hline Adek & Lon & Gohlom & Ji-woe-ih & Dari & LampOh. \\
\hline Brother & My & Not yet & 3-go home-3 & Prep & Garden \\
\hline \multicolumn{6}{c}{ 'My brother is not going home yet from the garden' } \\
\hline
\end{tabular}

\begin{tabular}{lllllll}
\hline Pue & Abang & Jadéh & Neu-èh-neuh & U & Rumoh & Lon? \\
\hline Do & Brother & Agree & 3-sleep-3 & Prep & House & My? \\
\hline \multicolumn{6}{c}{ 'Do you sleep at my house?' } \\
\hline
\end{tabular}

\begin{tabular}{lllllll}
\hline Menyoe & Jeut & Gata & Ta-jak-teuh & U & kauri & Nyan. \\
\hline If & Could & You & 2-go-2 & Prep & Party & That \\
\hline \multicolumn{6}{c}{ 'Please go to that party if you could.' } \\
\hline
\end{tabular}

From the above examples, we can see that proclitic geu- and enclitic-geuh are attached to the verb manoe or 'bath' (32), proclitic $j i$ - and enclitic - $i h$ are attached to the verb woe 'go home' (33), proclitic neu- and enclitic -neuh are attached to the verb èh 'sleep' (34), and proclitic ta- and enclitic-neuh are attached to the verb jak 'go' (35). The function of using the 
combination of proclitic and enclitic to the same verb in one sentence is to emphasize the topic being talked by the subject.

In Acehnese, enclitic cannot be combined with proclitic to the same verb that contains the meaning of action, either transitive of intransitive. The following examples are transitive sentences.

(36)

\begin{tabular}{llllll}
\hline Lon & Hana & Jadéh & Lon-bloe & Bajee & Nyan. \\
\hline I & Not & Agree & 1-buy & Cloth & That \\
\hline \multicolumn{5}{c}{ 'I postpone buying that cloth.' } \\
\hline \multicolumn{6}{c}{}
\end{tabular}

(37)

\begin{tabular}{llllll}
\hline Lon & Hana & Jadéh & Lon-bloe(*-lon) & Bajee & Nyan. \\
\hline I & Not & Agree & 1-buy-1 & Cloth & That \\
\hline \multicolumn{5}{c}{ 'I postpone buying that cloth.' } \\
\hline
\end{tabular}

The verb bloe 'buy' can be attached to proclitic lon-bloe (36), but it cannot be attached to enclitic lon-bloe (*-lon) (37) because the verb requires the actor and the target that there is a deliberate thing done by the subject as the actor. Intransitive verbs also follow the same pattern as can be seen in the following examples.

(38)

\begin{tabular}{llll}
\hline Gobnyan & Geu-bloh & Lam & Parèk. \\
\hline $\mathrm{He}$ & 3-jump & Prep & Ditch \\
\hline \multicolumn{4}{c}{} \\
\hline
\end{tabular}

(39)

\begin{tabular}{llll}
\hline Gobnyan & Geu-bloh(*-geuh) & Lam & Parèk. \\
\hline $\mathrm{He}$ & 3-jump & Prep & Ditch \\
\hline \multicolumn{4}{l}{} \\
\hline
\end{tabular}

The verb bloh 'jump' can be attached to proclitic lon-bloh (38), but it cannot be attached to enclitic geu-bloh (*-geuh) (39) because the subject is doing an action mentioned in the predicate, so enclitic cannot be attached.

From the research results, it can be seen that the proclitic and enclitic of the Acehnese are various according to pronouns that precede or follow them. Each pronoun has its own unchangeable proclitic and enclitic pair. These kinds of characteristics are not found in any other languages. In English, for example, the clitic is produced not from the pronouns but it is produced from the reduction of the auxiliary verbs embedded at the beginning of the word, for the proclitic and at the end of the word for the enclitic (Bauer, 1988:100; Katamba, 1993:245). Take as an example, the proclitic ' $d$ ' is produced from from the reduction of auxiliary verbs 'do' as in the phrase d'you need to decide today? The enclitic "ve' is the reduction of the word 'have' as in the sentence they 've decided against it.

If in the Acehnese and English, it is known only proclitic and ecnlitic, there are languages that have endoclitic. Harris (2002) defines endoclitic as a clitic attached to the word. The existence of endoclitic is initially questioned by many experts as opposed to the lexical integrity hypothesis. However, the evidence in Udi (Harris, 2002), Pashto (Kopris and Davis, 1988), and Degema (Kari, 2003) show that some languages have endoclitic features. Other languages in the world must also have its own distinct characteristics. This fact proves that every language has a uniqueness.

\section{CONCLUSION}

This research concludes that clitic in Acehnese consists of proclitic and enclitic. Proclitic is used to refer to a noun or noun phrase. Each personal pronoun has its own proclitic and enclitic including the conformity clitic for variant personal pronouns to the politeness level. Enclitic in the Acehnese does not only function as the conformity because it is semantically in charge of the actors. The use of enclitic in the Acehnese describes that potentially, agents have control over the events stated in the predicate. If the clitic does not exist in this language, the control of actors becomes low. The clitic always demands the presence of agents in both explicit and implicit sentences. In the nonformal variety, the presence of actors in a sentence is optional because inherently clitic already refers to the actors although it is not stated explicitly. Thus, the morphology of clitics in the Acehnese can be used as a marker of active diathesis, even though the Acehnese clitics can also be used in passive sentences. In addition, proclitic and enclitic in Acehnese can be combined and attached to the same verb in one sentence which has a function to emphasize the topic being talked by the subject.

\section{REFERENCES}

Asyik, A.G. (1987). A contextual grammar of acehnese sentences. Disertasi. Michigan: The University of Michigan.

Bauer, L. (1988). Introducing linguistic morphology. Edinburg: Edinburg University Press.

Chatzikyriakidis, S. (2010). Clitics in four dialects of modern greek: a dynamic account. Disertasi.University of London: Department of PhilosophyKing's College London.

Creswell, J.W. (2009). Research design; Qualitative, quantitative, and mixed methods approaches $\left(3^{\text {rd }} \mathrm{ed}\right.$.). The USA: Sage.

Djajasudarma, T. F. (2006). Metode linguistik: ancangan metode penelitian dan kajian. Bandung: Eresco.

Djunaidi, A. (1992). Morfosintaksis bahasa Aceh: analisis tipologi sintaksis. Tesis. Bandung: Unpad.

Djunaidi, A. (1996). Relasi-relasi gramatikal dalam bahasa aceh: satu telaah berdasarkan teori tata bahasa relasional. Disertasi. Bandung: Unpad.

Durie, M. (1985). A grammar of Achenese on the dialect of North Aceh. Dordrecht-Holland/Cimnnamison USA: Foris Publication.

Grüter, T. (2006). Object clitics and null objects in the acquisition of french. Disertasi. Montreal: Department of Linguistics, McGill University.

Halpern, A.L. (1998). Clitics. In Spencer, A. and A. M. Zwicky (eds.), The Handbook of Morphology. Oxford: Blackwell Publishers.

Harris, A.C. (2002). Endoclitics and the Origins of Udi Morphosyntax. Oxford: Oxford University Press 
Hudson, R. (2007). Clitics in Word Grammar. Retrieved from http://www. phon.ucl.ac.uk/home/dick/wg.htm. on 5 January 2018.

Iqbal, M. (2011). Diatesis aktif bahasa aceh: analisis morfosintaksis. Tesis. Bandung: Unpad.

Kari, E.E. (2003). Clitics in Degema: A Meeting Point of Phonology, Morphology, and Syntax. Tokyo: Research Institute for Languages and Cultures of Asia and Africa.

Katamba, F. (1994). Modern Linguistics: Morphology. London: The Macmillan Press Ltd.

Kaufman, D.A. (2010). The morphosyntax of tagalog clitics: a typologically driven approach. Disertasi. New York: Faculty of the Graduate Schoolof Cornell University.

Kopris, C.A. and Anthony R. D. (1988). Theoretical Morphology Approaches in Modern Linguistics. San Diego: Academic Press.

Martín, F.J. (2012). Deconstructing catalan object clitics. Disertasi.New York: Department of Linguistics.

Medová, L. (2009). Reflexive clitics in the slavic and romance languages: a comparative view from an antipas- sive perspective. Disertasi. Faculty of Princeton University, Department of Slavic Languages And Literatures.

Muhadjir, N. (1996). Metodologi Penelitian Kualitatif. Edisi ketiga. Yogyakarta: Rakesarasin.

Salmons, I.O. (2015). The agrammatic comprehension of contrastive focus and clitic left dislocation in catalan. Disertasi. Universitat Autonoma de Bercelona: Fakultat de Filosofia I Lietres.

Schiering, R. (2006). Cliticizationand the volution of morphology: a cross-linguistic study on phonology in grammaticalization. Disertasi. Universitas Konstanz Fachbereich Sprachwissenschaft.

Spencer, A. and Zwicky, A.M. (2001). The Handbook of Morphology (Ed.). Oxford: Blackwell Publisher.

Sudaryanto. (1992). Metode Linguistik. Yogyakarta: Gadjah Mada University Press.

Verhaar, J. W. M. (1996). Asas-AsasLinguistik Umum. Yogyakarta: Gadjah Mada University Press.

Wildan, W. (2010). Kaidah Bahasa Aceh. Banda Aceh: Geuci. 